\title{
Economic Viability of Cocoa Production under Different Management Systems Edo State, Nigeria.
}

\author{
Osarenren, C. O \\ Edo State College of Agriculture, Iguoriakhi, Nigeria.
}

\begin{abstract}
This study assessed the viability of cocoa production under different management systems in Edo State, Nigeria with the view of choosing the best management system to be adopted by the farmers. It focuses specifically on the variability of the various management systems identified as well as the constraint peculiar to the different management systems in study area. A multistage sampling technique was used to select 182 cocoa farmers in the study area while structured questionnaire and interview schedule were used to collect data from the respondents. Data were analyzed using investment decision model comprising of the Net Present Value $(N P V)$, Benefit Cost Ratio (BCR) and Internal Rate of Return (IRR). From the NPV, BCR and IRR analysis at $19 \%$ discount rate, the three management systems were viable. The estimate of NPV $(\mathrm{N}$ 119,918.19) and IRR (30.04\%) for owner managed systems was the highest, meaning that, it was the most economically and financially viable management system practiced by the farmers. The BCR for all the management system were greater than one which confirmed viability of the enterprises. However, leased management system was the least viable relative to owner managed and share crop managed system. The major constraints faced by the farmers were lack of finance, credit accessibility and pest problem, inadequate storage facilities, inadequate processing facilities. It was recommended that farmer in study area should be encouraged to choose the owner managed system of cocoa farming production system over the share crop and leasehold management farm system base on the viability of the enterprise. Also investment in cocoa production should be increased tremendously by providing expanded access to cheap and flexible credit, as finance presented a major limiting factor in cocoa production in the study area.
\end{abstract}

Key words: Cocoa, Production, Viability, Management Systems

\section{Introduction}

Cocoa (Theobroma cacao) belongs to the family Stericulinacea. Cocoa originated from the upper Amozon region of the South America from where it spread to different parts of the world (Osun, 2001). Cocoa has a high food value, containing as much as 20 percent protein, 40 percent carbohydrate, and 40 percent fat (Microsoft Encarta, 2009). It is also mildly stimulating because of the presence of theobromine, an alkaloid that is closely related to caffeine.

In Nigeria, cocoa has been and continues to be an important cash crop. It is also the largest non-oil export earner, a key contributor to wealth creation and poverty reduction, and the largest employer of labour (Central Bank of Nigeria, 2005). It contributes substantially to the foreign exchange earnings of the economy of which no single agricultural export commodity has earned more than cocoa (Dongo et al., 2009).

Commercial cocoa farming is one of the most important agricultural activities in tropical West Africa. It has over the years; improved on the living standards of farmers just as it stands as major foreign exchange earner for many West African countries. Cocoa farmers worldwide depend on cocoa for their livelihood with an annual world production of three million tonnes (WCF, 2009).

ICCO (2014) reported that, the total world consumption of cocoa was estimated to be 4.01 million tonnes by the end of 2014. This amount is slightly below 4million tonnes production for the period. Europe would likely continue to be the world's largest consuming area with about $47 \%$ of the global share of consumption, while all the developing countries put together would account for 1.3 million tonnes on the consumption scale. And these countries include Africa, Latin America, North America and Far East (ICCO, 2014).

Besides, there are reports of low productivities from cocoa farms in the country among other problems (Daniel, 2009). In fact, cocoa has declined in economic importance at the aggregate national level. Such uncertainties in productivity of a very important export crop calls for concern and gives threatening signals to realizing the sustainability potentials of the sub-sector.

Studies on this important farming sector in Nigeria has shown that, three management systems; ownership management, the leasehold, and the sharecropping systems are commonly practiced by farmers. But information on which of these systems is most economic to farmers in Edo State and the Nigerian economy in general is rare. This research is therefore conducted to establish the management system of cocoa farming that best suit the Nigeria economy and profits the farmers, especially in Edo State. 
The vital questions now are; which of the management systems is more economically viable? And what are the common varying problems associated with the management systems? In an attempt to answer these questions that this study aimed to analyzes the viability of cocoa production under different management systems in Edo State, Nigeria. The specific objectives were to determine the variability of the various management systems identified in the study area, and to identify the constraints peculiar to the different management systems in the study area.

\section{Methodology}

The study was carried out in Edo State, Nigeria. The State is bounded in the North by Kogi State, on the West by Ondo State, on the South by Delta State, in the East by Anambra States. A multistage sampling technique was adopted in choosing the respondents. The first stage involved delineation of the state into three according to the agricultural zoning of the State into Edo South, Edo Central and Edo North. The three zones were purposively chosen to give the study a wide focus. The second stage involved a purposive selection of Local Government Areas where cocoa production is dominant. Thus, in Edo South, Ovia South West and Ovia North East Local Government Area were purposively selected, in Edo north, Owan West and Owan East Local Government Area were chosen, while in Edo Central, Easn West Local Government Area was chosen making a total of five LGAs. Four communities were purposively selected from each of the LGA giving a total of 20 communities. The basis of selection was the dominance of cocoa production in them. Simple random was used to select cocoa farmer in each community.

Data Collection for the study data were obtained using the survey method with the administration of a well structured questionnaire assisted by personal interview schedule for non-literate farmers. Data Analysis was analyzed using investment decision model (Net Present Value (NPV) and Benefic-Cost Ratio). And The Likert scale adopted from Ugwoke et al. (2005), was used to assess the constraints facing the cocoa farmers under different management systems in the study area.

\section{The Investment Decision Model}

An investment decision model such as Net Present Value (NPV) and Benefic-Cost Ratio (BCR) were used to determine the viability of the various management systems identified in the study area. This estimating pattern was the most recent and has been used by other researchers including Nkang et al. (2007), who had it used in analyzing the most viable and profitable management system of cocoa production in Cross River State.

Net Present Value (NPV): The Net Present Value (NPV) is an important decision making tool by an investor to invest. The formal selection criterion for the net present value is to accept investments with NPV greater than zero. The formula is given as;

Where;

$$
N P V=\sum_{t=1}^{n} \frac{B_{t}-C_{t}}{(1+r)^{t}}
$$

$\mathrm{NPV}=$ Net present value, $\mathrm{Bt}=$ Discounted value of benefit (Revenue from sales of cocoa bean per Ha/annum) $\mathrm{Ct}=$ Discounted value of cost of production per hectare, $\mathrm{n}=$ Number of years; (for the period of five years), $\mathrm{t}$ $=1,2,3,4 \ldots, \mathrm{n}$ number of years, $\mathrm{r}=$ Rate of interest or rate of discount, $\sum=$ Sum of all.

Revenue from the sales of cocoa bean and cost of input (that is sum of the annual total revenues from the period of five years (2009- 2013)) were discounted for each year for the different management systems identified in the study area.

Benefit-Cost Ratio (BCR): The Benefit-Cost Ratio is another indicator used to determine the worthiness of an investment decision. It is given as the ratio of the sum of discounted benefits to the sum of discounted costs. It is represented as follows:

$$
B R C=\frac{\sum_{t=1}^{n} \frac{B_{t}}{(1+r)^{t}}}{\sum_{t=1}^{n} \frac{C_{t}}{(1+r)^{t}}}
$$

Where;

$\mathrm{B}_{\mathrm{n}}=$ Benefit in each year (Naira)

$\mathrm{C}_{\mathrm{t}}=$ Cost of each farming year (Naira)

$\mathrm{n}=$ Number of years

$\mathrm{r}=$ interest (discounted) rate $(\%)$

The decision rule is that for any project to be economically viable, the ratio must be greater than unity (Gittinger, 1982). And also BCR is greater than one; the business is viable, BCR equal to 1, breakeven point and BCR is less than 1: The business is not viable (Olukosi and Erhabor, 2005 and Emokaro et al., 2009). 
Economic Viability of Cocoa Production under Different Management Systems Edo State, Nigeria.

Internal Rates of Return (IRR)

Internal Rates of Return (IRR) is that rate of discount which will make the NPV of the project equal

to zero and is shown as follows:

$$
I R R=\sum_{t=1}^{n} \frac{B_{t}-C_{t}}{(1+r)^{t}}=0
$$

Where IRR = Internal Rates of Return

The decision criteria is that, if Internal Rates of Return is greater than or equal to discount rate (IRR $\geq$ r) then the project is viable (Obri et al., 2007)

\section{Constraints faced by the cocoa farmers.}

The Likert scale adopted from Ugwoke et al. (2005) was used to assess the constraints facing the cocoa farmers under different management systems in the study area. The scale was a five point scale Likert scale is a bi-polar scaling method measuring either positive or negative response to statement. The mean for determining the benchmark on which the constraints will be judged is given by the formula:

$$
X=\sum \frac{X_{1}}{N}
$$

Where; $\mathrm{i}=1,2,3, \ldots \mathrm{N}$

$\mathrm{N}=$ number of occurrence

$X=$ the assigned value of constraints (i.e. very serious $=5$, serious $=4$, moderate $=3$, not serious $=2$ and undecided $=1$ ).

$\sum=$ Sigma or summation sign .

\section{Results And Discussion}

\section{Viability of Cocoa Production under different Management Systems}

Table 1, 2 and 3 showed the Net Present Value, Benefit Cost Ratio and Internal Rates of Return computation of the respondents. The NPV was based on $19 \%$ discount rate for the period of five years studied. The result showed that, net present value was positive with value estimate of N119, 918.19, N75, 597.36 and N111, 524.72 for owner, leasehold and share crop managed systems respectively. The result indicated that the leasehold managed system was the least economically viable among the different systems. In addition, the benefit cost ratios were $3.05,2.88$, and 2.16 for owner managed, share crop managed and leasehold managed system respectively. Since all the Benefit Cost Ratios were greater than one, then all the management systems were economically viable. Finally, Internal Rates of Return were $30.04 \%, 25.77 \%$ and $5.57 \%$ for owner, share crop and leasehold managed systems respectively. The owner managed system was the most viable followed by the share crop and the leasehold managed systems were the least financially viable enterprise. Thus, the Net Present Value, the Benefit Cost Ratios and Internal Rates of Return indicated the viability of the various management systems of cocoa productions though at varying degrees. These positive and viable results are in agreement with the work of Nkang et al. (2007).

Table 1: Benefit Cost Ratio Analysis for Owner managed System

\begin{tabular}{|c|l|c|c|c|c|}
\hline & \multicolumn{5}{|c|}{ OWNER-MANAGED FARM } \\
\hline YEARS & Revenue & $\begin{array}{l}\text { Discount } \\
\text { factor (19\%) }\end{array}$ & $\begin{array}{l}\text { PV } \\
\text { Revenue) }\end{array}$ & Cost & PV (Cost) \\
\hline 1 & $46,639.60$ & 0.84 & $39,192.94$ & $14,857.40$ & $12,485.21$ \\
\hline 2 & $51,126.89$ & 0.71 & $36,104.01$ & $18,792.64$ & $13,270.70$ \\
\hline 3 & $54,969.36$ & 0.60 & $32,619.69$ & $20,333.24$ & $12,066.07$ \\
\hline 4 & $67,415.41$ & 0.50 & $33,617.96$ & $21,618.82$ & $10,780.63$ \\
\hline 5 & $88,332.57$ & 0.42 & $37,015.71$ & $23,933.94$ & $10,029.50$ \\
\hline TOTAL & $\mathbf{3 0 8 , 4 8 3 . 8 3}$ & & $\mathbf{1 7 8 , 5 5 0 . 3 0}$ & $\mathbf{9 9 , 5 3 6 . 0 4}$ & $\mathbf{5 8 , 6 3 2 . 1 1}$ \\
\hline
\end{tabular}

$\mathrm{NPV}=119,918.19 ; \mathrm{BCR}=3.05 ;$ IRR $=30.04 \%$

Table 2: Benefit Cost Ratio Analysis for Leasehold managed System

\begin{tabular}{|c|c|c|c|c|c|}
\hline & \multicolumn{5}{|c|}{ Leasehold-managed } \\
\hline YEARS & Revenue & $\begin{array}{l}\text { Discounted } \\
\text { factor } \\
(19 \%)\end{array}$ & $\begin{array}{c}\text { PV } \\
\text { (Revenue) }\end{array}$ & Cost & PV (Cost) \\
\hline 1 & $36,553.56$ & 0.84 & $30,717.28$ & $16,305.04$ & $13,701.71$ \\
\hline 2 & $40,070.46$ & 0.71 & $28,296.35$ & $20,645.03$ & $14,578.79$ \\
\hline 3 & $43,081.97$ & 0.60 & $25,565.52$ & $22,301.25$ & $13,233.91$ \\
\hline 4 & $52,836.51$ & 0.50 & $26,347.92$ & $23,708.76$ & $11,822.82$ \\
\hline 5 & $69,230.23$ & 0.42 & $29,010.88$ & $26,257.88$ & $11,003.35$ \\
\hline TOTAL & $\mathbf{2 4 1 , 7 7 2 . 7 3}$ & \multicolumn{5}{|c|}{$\mathbf{1 3 9 , 9 3 7 . 9 5}$} & $\mathbf{1 0 9 , 2 1 7 . 9 5}$ & $\mathbf{6 4 , 3 4 0 . 5 8}$ \\
\hline NPV= & $\mathbf{7 5 , 5 9 7 . 3 6 ,}$ & $\mathbf{B C R}=\mathbf{2 . 1 7}$, & IRR=5.57\% \\
\end{tabular}


Economic Viability of Cocoa Production under Different Management Systems Edo State, Nigeria.

Table 3: Benefit Cost Ratio Analysis for Sharecrop managed System

\begin{tabular}{|c|c|l|c|c|c|}
\hline & \multicolumn{5}{|c|}{ Sharecrop-managed } \\
\hline YEAR & Revenue & $\begin{array}{l}\text { Discounted } \\
\text { factor(19\%) }\end{array}$ & PV (Revenue) & Cost & PV (Cost) \\
\hline 1 & $44,597.97$ & 0.84 & $37,477.29$ & $15,004.20$ & $12,608.57$ \\
\hline 2 & $48,888.83$ & 0.71 & $34,523.57$ & $18,987.16$ & $13,408.06$ \\
\hline 3 & $52,563.09$ & 0.59 & $31,191.77$ & $20,528.68$ & $12,182.04$ \\
\hline 4 & $64,464.33$ & 0.50 & $32,146.35$ & $21,825.58$ & $10,883.73$ \\
\hline 5 & $84,465.84$ & 0.42 & $35,395.36$ & $24,167.07$ & $10,127.20$ \\
\hline TOTAL & $\mathbf{2 9 4 , 9 8 0 . 0 6}$ & & $\mathbf{1 7 0 , 7 3 4 . 3 3}$ & $\mathbf{1 0 0 , 5 1 2 . 6 9}$ & $\mathbf{5 9 , 2 0 9 . 6 1}$ \\
\hline
\end{tabular}

$\mathrm{NPV}=111,524.72 ; \mathrm{BCR}=\mathbf{2 . 8 8}, \mathrm{IRR}=25.77$

*Interest Rate was taken to be $19 \%$

\section{Production Constraints faced by Cocoa Farmers in the Study Area}

The major production constraints faced by cocoa farmers in the study area are shown in table 4 . It could be observed that a number of problems identified were; lack of finance with a mean of 4.91, 4.82 and 4.84 for owner managed, leasehold managed and share crop managed system respectively. This was followed by credit inaccessibility with mean of 4.81, 4.82 and 4.68 for owner, leasehold and share crop managed system. Previous works have shown credit inaccessibility as a constraint to farmers Adewale and Ogunniyi (2000), These authors posited that" rural banking scheme have not been very successful in granting attainment of its objectives of encouraging banking habits and granting of loans to agriculture". Other constraints considered serious, with means greater than 3.00, include pest problem, inadequate storage facilities, inadequate processing facilities, lack of access to machine, high cost of labour, inadequate access to agrochemical, fluctuating price of produce, and problem of sourcing for labour.

Table 4 Constraints of Cocoa Production under Different Management System in the Study Area

\begin{tabular}{|l|c|c|c|c|c|c|}
\hline \multirow{2}{*}{ Constraints } & \multicolumn{2}{|c|}{ Owner managed } & \multicolumn{2}{c|}{ Leased-managed } & \multicolumn{2}{c|}{ Sharecrop-managed } \\
\cline { 2 - 7 } & Mean & SD & Mean & SD & Mean & SD \\
\hline Lack of finance & $4.91^{*}$ & .36 & $4.82^{*}$ & .50 & $4.84^{*}$ & .55 \\
\hline Credit inaccessibility & $4.81^{*}$ & .57 & $4.82^{*}$ & .39 & $4.68^{*}$ & .69 \\
\hline Pest problem & $4.74^{*}$ & .62 & $4.45^{*}$ & .67 & $4.68^{*}$ & .90 \\
\hline Inadequate storage facilities & $4.47^{*}$ & .87 & $3.95^{*}$ & 1.05 & $4.24^{*}$ & .97 \\
\hline Highequate processing facilities & $4.44^{*}$ & .92 & $4.00^{*}$ & .87 & $4.40^{*}$ & .76 \\
\hline Lack of access to machine & $4.20^{*}$ & .81 & $4.05^{*}$ & .72 & $4.36^{*}$ & .76 \\
\hline Inadequate access to agrochemical & $4.05^{*}$ & 1.15 & $3.50^{*}$ & 1.14 & $4.08^{*}$ & 1.00 \\
\hline Fluctuating price of produce & $3.89^{*}$ & .96 & $3.50^{*}$ & .96 & $3.76^{*}$ & 1.01 \\
\hline Problem of sourcing for farm labour & $3.70^{*}$ & .93 & $3.59^{*}$ & .80 & $3.72^{*}$ & .74 \\
\hline Problem of land ownership, fragmentation & 2.82 & .99 & $3.10^{*}$ & .96 & $3.28^{*}$ & 1.14 \\
\hline Problem of marketing/transportation & 2.94 & 1.01 & 2.41 & 1.14 & 2.92 & 1.00 \\
\hline Lack of improved varieties & 2.51 & .83 & 2.41 & .73 & 2.60 & .91 \\
\hline Lack of Standard & 2.40 & 1.58 & 1.95 & 1.25 & 1.96 & 1.27 \\
\hline Soil fertility & 2.35 & .87 & 2.23 & 1.02 & 2.36 & .86 \\
\hline Weed problem & 2.18 & 1.64 & 2.09 & 1.57 & 2.72 & 1.84 \\
\hline
\end{tabular}

*Serious (mean> 3.00)

\section{Conclusions}

The empirical result obtained from this study shows that cocoa production economically viable in the study area. There is a high benefit relative to cost involved in cocoa production irrespective of the management system. All three management systems of cocoa production identified in the study area are economically viable. Investment of cocoa production at any level in the study area is justifiable. The major constraints faced by the farmers were lack of finance, credit accessibility and pest problem. It is thus recommended that farmer in study area should be encouraged to choose the owner managed system of cocoa farming production system over the share crop and leasehold management farm system base on the viability of the enterprise. Also investment in 
cocoa production should be intensified by providing expanded access to cheap and flexible credit to the farmers as finance presented a major limiting factor in cocoa production in the study area.

\section{References}

[1]. Adewale J G and LT Oguniyi (2000). "Assessment of the Rural Banking Scheme in OgbomoZone of Oyo State". NigerianAgricultural Development Studies; Vol. 1, No. 1, PP 1 -6, March.

[2]. Central Bank of Nigeria, CBN (2005). Annual Report and Statement of Account.CBN, Abuja.

[3]. Daniel A (2009). Problems and Prospects of Commercial Small and Medium Scale Cocoa and Oil Palm Production In Cross River States Nigeria. Unpublished B.Sc Thesis submitted to the Department of Agricultural Economics and Extension, Enugu State University of Science and Technology.

[4]. Dongo LN, Aigbekaen EO, Jayeola CO, Emaku LA and Orisajo SB (2009). Influence of farmers practices on cocoa bean quality: Nigeria field experience. Afria Crop Science conference proceedings, vol. 9.pp299-302.

[5]. Emokaro CO, Ekunme PA and Achille, A. (2009). Profitability and Viability of Catfish Farming in Kogi State, Nigeria Research Journal of Agricultural and Biological Science. 5(7): 776-779.

[6]. Gittinger JP (1982). Economic Analysis of Agricultural Projects, John Hopkins University Press, Baltimore, Maryland, USA.

[7]. International Cocoa Organization, ICCO (2014). International Cocoa Organization Regional Seminar on the functioning of cocoa futures markets and Econometric Modelling of the cocoa market. Indonesia, July 2014.

[8]. Microsoft Encarta (2009). Cocoa. Microsoft ${ }^{\circledR}$ Encarta ${ }^{\circledR} 2009$ [DVD]. Redmond, WA: Microsoft Corporation.

[9]. Nkang M, Aja EA, Aban SO and Edet EO (2007). Investment in cocoa production in Nigeria: a cost and return analysis of three cocoa production management systems in the cross river state cocoa belt. Journal of Central and European Agriculture Volume 8 (1): 81-90.

[10]. Obiri DB, Geoff AB, Morag AM, Anglaare LCN. and Cobbina J (2007). Financial Analysis of Shaded Cocoa in Ghana, Agroforestry Systems 71:139-149.

[11]. Olukosi JO and PO Erhabor (2005). Introduction to farm management principles and Applications.AGITAB Publishers, Zaira Samaru.P 77.

[12]. Ugwoke FO, Mathews-Njoku EC and Onu DO (2005). Constraints to self-employment in farming: case of participant in the Agricultural Sector Employment programme in Enugu State.

[13]. Osun T (2001). Analysis of socio-economic factors affecting cocoa production in OndoState: case study of Idanre and Ondo East Local GovernmentArea. B.Sc Thesis in the Department of Agricultural Economics, Ondo State University, Akure.

[14]. World Cocoa Foundation, WCF (2009). Encouraging Sustainable Responsible Cocoa Growing.www.worldcocoafoundation.com/cocoafacts and figures. 